Igor Ivašković*

Pregledni znanstveni rad

UDK 94(497.1):342

DOI: https://doi.org/10.25234/pv/10902

Rad primljen: 10. svibnja 2020.

Rad prihvaćen: 9. studenoga 2020.

\title{
POLEMIKE O STATUSU DRŽAVE I KRALJEVINE SHS
}

Sažetak: Temeljna je ambicija ovog članka analizirati pitanje pravnog (dis)kontinuiteta izmedu Kraljevine Srbije i Kraljevine SHS u kontekstu medunarodnog spora između Njemačke i Kraljevine SHS te pritom otkriti uzroke različitih tumačenja presude u predmetnom sporu. Autor najprije, služeći se tehnikama povijesnopravne i analitičke metode pri proučavanju dokumenata i sekundarnih mišljenja političara te ustavnih pravnika, daje kratak pregled međunarodnih okolnosti koje su omogućile formiranje poslijeratnih država, nakon čega sažima različite stavove o pravnom statusu Države SHS i karakteru Prvoprosinačkog akta, koristeći pritom tadašnje $i$ današnje međunarodnopravne $i$ ustavnopravne kriterije. Nakon toga u okviru razmatranja središnjeg pitanja zaključuje kako je tadašnje tumačenje Ivana Žolgera, kako je unatoč presudi u predmetnom sporu Kraljevina SHS ipak bila nova država jer ista nije stvorena u skladu s Ustavom Kraljevine Srbije, pravno najdosljednije. Pored konstatacije kako je Država SHS zadovoljavala temeljne kriterije državnosti te da je formiranje Kraljevine SHS prekinulo ustavnopravni kontinuitet Kraljevine Srbije, doprinos studije očituje se i kroz argumentaciju kako različita pravna shvaćanja u ovom predmetu ipak nisu bila toliko rezultat pravnih dvoumica, već su u prvom redu bila odraz jedne od mnogih političkih bitaka između sukobljenih državnih ideologija.

Ključne riječi: $\quad$ ustavno pravo, Kraljevina SHS, Kraljevina Srbija, Država SHS, jugoslavenstvo

Dr. sc. Igor Ivašković, docent Ekonomskog fakulteta Univerziteta u Ljubljani, Kardeljeva ploščad 17, 1000 Ljubljana. E-adresa: igor.ivaskovic@ef.uni-lj.si. ORCID: https://orcid.org/0000-0002-3474-007X. 


\section{UVOD}

Prvi je svjetski rat rezultirao kristalizacijom različitih južnoslavenskih državnih vizija koje su međusobno prema temeljnim geopolitičkim odrednicama nerijetko bile u suprotnosti jedna s drugom. Dio je Slovenaca i Hrvata naime polagao velike nade u očuvanje Habsburške Monarhije i unutar iste u uspostavu zasebne hrvatske, odnosno šire južnoslavenske jedinice koja bi bila ravnopravna austrijskom i ugarskom dijelu. Istovremeno je političko vodstvo Kraljevine Srbije nakon prevrata 1903. upravo Habsburšku Monarhiju doživljavalo kao glavnu prijetnju svojim državnim vizijama. Potonje su, unatoč ideji priključivanja hrvatskih i slovenskih teritorija, isključivale svaku mogućnost kako podređivanje Srbije habsburškom državnom okviru ${ }^{1}$ tako i svaku mogućnost uključivanja u južnoslavensku državu s katoličkom većinom. To je, dakle, impliciralo pristajanje samo na državu sa središtem u Srbiji i pod kontrolom vladajuće srpske političke elite.

Različite su se vizije budućnosti odrazile i na pravne te političke akte koje su različite strane objavljivale tijekom Prvog svjetskog rata. S jedne su strane glavni elementi Svibanjske (Majske) deklaracije iz 1917. bili habsburški državni okvir ${ }^{2}$ i hrvatsko povijesno državno pravo, ${ }^{3}$ dok se na drugoj strani kao preduvjet zajedničke države isticala vladavina kraljevske dinastije Karađorđević. ${ }^{4}$ Ako i uzmemo u obzir teze pojedinih povjesničara kako je spominjanje Habsburgovaca u Svibanjskoj deklaraciji bila samo taktička, tj. neiskrena klauzula, ${ }^{5}$ koncept hrvatskog državnog prava je nesporno u dobrom dijelu hrvatskih političkih grupacija ipak bio osnovom svakog razmišljanja o državnoj budućnosti Hrvata, što je, dakako, bilo u suprotnosti s temeljnom paradigmom srpskih državnih ideja. Te suprotnosti nisu u potpunosti nestale ni u jednom razdoblju Kraljevine Srba, Hrvata i Slovenaca (Kraljevina SHS), odnosno Kraljevine Jugoslavije, a ovaj članak ima ambiciju prikazati kako su se ti različiti stavovi na pravnom području sukobili već kod pitanja interpretacije samog akta formiranja poslijeratne države. U prvom se dijelu daje kratak pregled međunarodnih okolnosti koje su omogućile formiranje Države Slovenaca, Hrvata i Srba (Država SHS) i njezino spajanje s Kraljevinom Srbijom, potom se analiziraju političke reakcije te interpretacije Prvoprosinačkoga akta u međunarodnim sudskim procesima i kod tadašnjih međunarodnopravnih i ustavnopravnih stručnjaka s ciljem valorizacije različitih stavova o pravnom (dis)kontinuitetu između Kraljevine Srbije i Kraljevine SHS.

1 Čulinović, F., Tri etape nacionalnog pitanja u jugoslovenskim zemljama, Jugoslavenska akademija znanosti i umjetnosti, Zagreb, 1962., str. 24.-25.

2 Prunk, J.; Toplak, C.; Hočevar, M., Parlamentarna izkušnja Slovencev, Fakulteta za družbene vede, Ljubljana, $2006 .$, str. 72.

3 Sirotković, H.; Margetić, L., Povijest država i prava naroda SFR Jugoslavije, Školska knjiga, Zagreb, 1988., str. 224.

4 Popov, Č.; Mitrović, A., Istorija srpskog naroda. Knjiga šesta. Od Berlinskog kongresa do ujedinjenja 1878-1918, Srpska književna zaklada, Beograd, 1983., str. 41.

5 Lukan, W., Iz „črnožolte kletke narodov“ v „zlato svobodo“? Habsburška monarhija in Slovenci v prvi svetovni vojni, Znanstvena založba Filozofske fakultete Univerze v Ljubljani, Ljubljana, 2014., str. 85. 


\section{POSLIJERATNE OKOLNOSTI I ZNAČENJE ŽENEVSKE DEKLARACIJE}

Na konačni oblik južnoslavenske države ključno je utjecao ishod Prvog svjetskog rata koji je poremetio dotadašnje odnose snaga u široj međunarodnoj zajednici. Kraj rata hrvatska je politička elita dočekala rascijepljena, no ideal hrvatske države živio je u brojnim političkim grupacijama i izvan pravaških stranaka, ${ }^{6}$ iako je činjenica da je od razdoblja rađanja takozvane politike „novog kursa“ bilježen trend jačanja Hrvatsko-srpske koalicije (HSK). Ipak, istraživanja pokazuju kako je i u potonjoj nekima, bar kod dobrog dijela hrvatskih predstavnika, primarni cilj bilo državno-pravno povezivanje hrvatskih područja, što je trebalo biti osnovom za eventualno povezivanje ostalih južnoslavenskih teritorija u Habsburškoj Monarhiji. To je bilo iskazano i skupom političara iz Hrvatske i Slavonije, Dalmacije, Bosne i Hercegovine (BIH), Istre, Međimurja, Kranjske i ostalih slovenskih područja koji se održao 3. ožujka 1918. u Zagrebu, gdje je ispostavljen zahtjev za uspostavom neovisne države Slovenaca, Hrvata i Srba, a regionalne su političke organizacije u Dalmaciji, Hrvatskom primorju i Istri također u prvi plan postavile spajanje hrvatskih teritorija i tek nakon toga širu južnoslavensku zajednicu. ${ }^{7}$ Istovremeno se određeni dio tih političara potajno nadao kako habsburška vlast ipak neće dopustiti ostvarenje i onog dijela političkog programa s kojim je HSK privukao srpske političke predstavnike na hrvatskim područjima, a to je uz opredjeljivanje političkog subjektiviteta Srba u Zadarskoj rezoluciji ${ }^{8}$ bilo i pogledavanje prema Beogradu u kontekstu državnog povezivanja. ${ }^{9}$ Također je i na slovenskoj strani, iako su pojedini historiografski radovi koji su nastali u specifičnom kontekstu između dva svjetska rata pokušavali predstaviti drugačiju sliku, ${ }^{10}$ tek tijekom rata prevladao stav o rješavanju slovenskog pitanja izvan, a ne unutar Habsburške Monarhije. ${ }^{11}$ Porazi austrougarske vojske i posljedično urušavanje Habsburške Monarhije te istovremeno nespremnost bečkih i još manje mađarskih političkih elita da udovolje prije svega višestoljetnim hrvatskim, ${ }^{12}$ no i slovenskim ambicijama o političkoj emancipaciji, ${ }^{13}$ potaknulo je njihove političke predstavnike na raskid svih državnih spona s Austro-Ugarskom u listopadu 1918. Dakako, tome je bitno pridonijela i informacija kako će sile Antante ipak dopustiti rasformiranje Habsburške Monarhije. ${ }^{14}$ Već prije toga, deklaracijom od 19. listopada 1918., na cijelom je južnoslavenskom području Habsburške Monarhije vlast preuzelo Narodno vijeće Slovenaca, Hrvata i Srba koje je isti dan odbacilo Manifest cara (kralja) od 16. listopada kao i

6 Treba dakako napomenuti da nisu sve pravaške opcije zastupale ideju samostalne hrvatske države. Starčevićeva stranka prava se naime zalagala za širu jugoslavensku opciju, no s federalnim uređenjem (Kovač, M., Raspadanje Austro-Ugarske i rađanje Kraljevine SHS u svjetlu francuske politike (od listopada do prosinca 1918.), Časopis za suvremenu povijest, god. 35, br. 1, 2003., str. 143.144.)

7 Koprivica-Oštrić, S., Konstituiranje Države Slovenaca, Hrvata i Srba 29. listopada 1918. godine, Časopis za suvremenu povijest, god. 25, br. 1, 1992., str. 48.-49.

8 Pilar, I., Južnoslavensko pitanje: prikaz cjelokupnog pitanja/L.V. Südland, Hrvatska demokratska stranka, Varaždin, 1990., str. 346. Ivašković, I., The Implications of the “New Course” Strategy, Croatian Political Science Review, god. 56, br. 3-4, 2019., str. $218 .-238$.

Lavrič, J.; Mal, J.; Stele, F. (ur.), Spominski zbornik Slovenije, Jubilej, Ljubljana, 1939

Perovšek, J., Slovenska osamosvojitev v letu 1918, Modrijan, Ljubljana, 1998., str. 13.

Čepulo, D.; Margetić, L.; Beuc, I., Hrvatska pravna povijest u europskom kontekstu, Pravni fakultet, Zagreb, 2006., str. 113.-122.

Stavbar, V., Majniška deklaracija in deklaracijsko gibanje, Založba Pivec, Maribor, 2017., str. 55.-60.

Pleterski, J., Prva odločitev Slovencev za Jugoslavijo, Slovenska matica, Ljubljana, 1971., str. 202. 
svaki budući prijedlog koji bi pokušavao parcijalno rješavati pitanje Slovenaca, Hrvata i Srba na području Monarhije. ${ }^{15}$ Deset je dana nakon toga u Hrvatskome saboru proglašena Država SHS, ${ }^{16}$ čime se preduhitrilo pokušaje uspostavljanja sovjetskih republika prema boljševičkom modelu. ${ }^{17}$

Članovi Narodnog vijeća SHS bili su izloženi pritisku vanjskih čimbenika, posebice ratnih pobjednika, koji nisu željeli dopustiti formiranje država bez njihova nadzora. Pri tom su prednjačile francuska i britanska diplomacija. Dok se potonja već 1915. Londonskim paktom obvezala teritorijalno namiriti Italiju i Srbiju, prva je tražila saveznika koji će obuzdati talijansko širenje i ujedno neće slijediti njemačke interese na drugoj strani Alpa. ${ }^{18} \mathrm{Ne}$ iznenađuje stoga da su upravo britanska i francuska diplomacija potaknule razgovore predstavnika Države SHS i Nikole Pašića, predsjednika vlade Kraljevine Srbije. Uslijedili su kratki pregovori i potpisivanje Ženevske deklaracije 9. studenog 1918. kojom je bilo propisano uspostavljanje zajedničke jugoslavenske države, a ujedno je buduća ustavotvorna skupština opunomoćena za odlučivanje o temeljnim pitanjima državnoga uređenja. Potpisivanjem sporazuma, koji je predviđao federativne temelje spajanja Države SHS i Kraljevine Srbije, srpska vlada je ne samo priznala legitimnost Narodnome vijeću SHS kao predstavniku Države SHS, već je priznala i ravnopravnost dvaju državnih entiteta. ${ }^{19}$ To je ustvrdio i sam Pašić u svojoj izjavi neposredno pred konferenciju 25. listopada iste godine: "Srbi ne želimo zauzimati hegemonski stav u budućem Kraljevstvu SHS. Svečano izjavljujem da Srbija smatra nacionalnom dužnošću oslobađanje Srba, Hrvata i Slovenaca. Oslobođeni će imati pravo na samoodređenje, tj. pravo izjaviti žele li se pridružiti Srbiji u smislu Krfske deklaracije ili žele formirati neovisne države. Ne dozvoljavamo da bi se Hrvatima i Slovencima pravo na samoodređenje na kojigod način ograničavalo. Čak i na Krfskoj deklaraciji nećemo inzistirati, ako ista nije u skladu s njihovim željama." ${ }^{20}$ Ta je izjava odražavala duh trenutka u kojem se veličalo načelo samoodređenja naroda, koje je pod utjecajem Sjedinjenih Američkih Država (SAD) barem deklarativno pobjedonosna Antanta prikazivala kao jedan od svojih najvažnijih doprinosa međunarodnim odnosima i pravu. Pašić očigledno to nije smio ignorirati u svojim govorima, no također je bio svjestan boljeg polazišnog položaja Srbije u odnosu na Hrvate i Slovence. Potonjim se doduše dopuštala iluzija o slobodnom odlučivanju o zajedničkoj državi sa Srbima ili o neovisnoj državi, ali bi se pritom uvijek davalo na znanje kako bi ta potencijalna neovisna država Slovenaca i Hrvata ostala bez područja na koja su države pobjednice, Italija i Srbija, pretendirale i koja su im uostalom bila obećana Londonskim paktom. Hrvatska bi, dakle, vrlo teško opstala kao neovisan međunarodni entitet, a isto vrijedi i za područja naseljena Slovencima.

S obzirom na navedene okolnosti Ženevska je deklaracija bila značajno političko postignuće Ante Trumbića i Antona Korošeca koji su s pojedinim članovima srpske oporbe uspjeli pri-

\footnotetext{
15 Boban, L., Kada je i kako nastala Država Slovenaca, Hrvata i Srba, Časopis za suvremenu povijest, god. 24, br. 3, 1992., str. $45 .-60$.

16 Sirotković, H., O nastanku, organizaciji, državnopravnim pitanjima i sukcesiji Države SHS nastale ujesen 1918., Časopis za suvremenu povijest, god. 24, br. 3, 1992., str. 61.-74.

17 Banac, I., Emperor Karl Has Become a Comitadji: The Croatian Disturbances of Autumn 1918, The Slavonic and East European Review, god. 70, br. 2, 1992., str. 301.

18 Kovač, M., op. cit. u bilj. 6, str. 141.-172.

19 Perovšek, J., Jugoslovanska združitev, u: Borak, N.; Fisher, J. (ur.), Slovenska novejša zgodovina 1848 - 1992, Mladinska knjiga, Inštitut za novejšo zgodovino, Ljubljana, 2005., str. 200.-201. 
dobiti Pašićev pristanak na nagodbu koja je trebala biti temelj nekoj novoj dvojnoj državi. ${ }^{21}$ Sporazum je naime sadržavao kako federalne tako i konfederalne elemente na kojima bi buduća ustavotvorna skupština trebala temeljiti svoj rad. Takvu bi novu državu trebala voditi dvanaesteročlana vlada, i dok bi polovicu ministara predložila srpska vlada te bi isti polagali prisegu srpskome kralju, drugi bi dio vlade predložilo Narodno vijeće SHS čijemu bi predsjedniku prisegnula druga šestorica ministara. ${ }^{22}$ Ženevska je deklaracija, dakle, za razliku od Krfskog sporazuma, uskratila prepuštanje vlasti dinastiji Karađorđević nad cijelim područjem buduće države, jer bi, barem do usvajanja Ustava, Narodno vijeće trebalo imati funkciju vrhovne vlasti na teritoriju Države SHS. Upravo je to bio glavni uzrok da na kraju srpska vlada ipak nije potvrdila dogovor. ${ }^{23}$ Štoviše, 13. studenog u Zagreb stiže srpski potpukovnik Svetislav Simović u funkciji delegata Kraljevine Srbije pri Narodnom vijeću SHS, koji suočava hrvatsku stranu sa zbiljom. On naime nabraja teritorije, uključujući cijelu BIH, veliki dio Dalmacije i polovicu Slavonije, te zaključuje kako će nabrojeno u svakom slučaju postati dio Srbije, a zapadno od toga Hrvati i Slovenci mogu se odlučiti žele li sa Srbijom ili će stvarati zasebnu državu. ${ }^{24}$

\section{OKOLNOSTI PRVOPROSINAČKOG AKTA I REAKCIJE NAKON NJEGA}

Vojvodina se pridružila Srbiji tijekom samih pregovora predstavnika Države SHS i srpske vlade. Činjenica je kako Narodno vijeće SHS na području Vojvodine nije imalo značajniji politički utjecaj koji bi bio poduprt i mogućnošću aktivacije vojne sile, dok je upravo suprotno srpska vojska tada već bila nagomilala svoje snage u toj pokrajini. Odmah nakon priključenja Vojvodine u Crnoj je Gori srušena vlast kralja Nikole Petrovića te je proglašeno ujedinjenje države sa Srbijom. U Hrvatskoj su se u tom razdoblju formirala dva bloka, što se odrazilo i na djelovanje Narodnog vijeća SHS. S jedne su strane pojedini članovi zajedno s Jugoslavenskim odborom nastojali postići međunarodno priznanje Države SHS, dok je druga strana predvođena Svetozarom Pribićevićem nastojala postići ujedinjenje sa Srbijom što je prije moguće i to bez prethodnoga međunarodnog priznanja Države SHS. Tomu se najoštrije protivio Stjepan Radić sa svojim brojnim govorima upozorenja, a među najpoznatijima je bio sljedeći: "Gospodo! Još nije prekasno! Ne srljajte kao guske u maglu! Ne zaključujte jedinstvene vlade s Kraljevinom Srbijom već zato, jer, eto, u ime Kraljevine Srbije nema tu nikoga, ništa, osim jedan brzojav, a i taj predstavlja nešto drugo nego vi. Nemojte tako postupati da se bude moralno danas-sutra kazati, da ste i vi Slovenci i vi Srbi Vojvođani i Bosanci, i vi naši Hrvati Dalmatinci, a nadasve vi naši domaći hrvatski Srbi, da ste se svi skupili danas ovamo samo zato da izvršite jedno urotničko djelo protiv naroda, napose protiv Hrvatske i Hrvata." 25 U kontekstu formira-

21 Lampe, J. R., Yugoslavia as history. Twice there was a country. Second edition, Cambrige University press, Cambridge, 2002., str. 111.

22 Rahten, A., Slovenska ljudska stranka v beograjski skupščini. Jugoslovanski klub v parlamentarnem življenju Kraljevine SHS 19191929, Založba ZRC, Ljubljana, 2002., str. 26.

23 Engelsfeld, N., Povijest hrvatske države i prava - razdoblje od 18. do 20. stoljeća, Pravni fakultet, Zagreb, 2002., str. 277.; Perovšek, J., op. cit. u bilj. 19, str. 201.

24 Krizman, B., Hrvatska u prvom svjetskom ratu: hrvatsko-srpski politički odnosi, Globus, Zagreb, 1989., str. 337. 
nja različitih alternativnih državnopravnih programa Radić je često posezao za SAD-om, koji je bio istovremeno pobjednik u ratu i najsnažniji zagovornik instituta narodnog samoopredjeljenja. ${ }^{26}$ Tako je prema uzoru na SAD predložio i stvaranje hrvatske države koja bi bila utemeljena na hrvatskom državnom pravu i načelu samoopredjeljenja. Potraga za nacionalnim alternativama temeljila se na osnovnoj pretpostavci da Država SHS treba više vremena kako bi mogla ravnopravno pregovarati o (kon)federalnom povezivanju sa Srbijom jer u danim okolnostima Hrvatima prijeti opasnost od centralističkog i unitarističkog režima u kojem bi jednako kao i ostali nesrpski južnoslavenski narodi postali samo privjesak Srbiji: “Gospodo! Vama su svima puna usta riječi: narodno jedinstvo - jedinstvena država, jedno kraljevstvo pod dinastijom Karađorđevića. I svi mislite da je to dosta govoriti da smo mi Hrvati, Srbi i Slovenci jedan narod zato što govorimo jedan jezik, pa da zato moramo imati i jedinstvenu centralističku državu, i to kraljevstvo, i da nas samo to, takvo jezično i državno jedinstvo pod dinastijom Karađorđevića može spasiti i usrećiti...Vi, dakle, naš narod plašite kao malu djecu i mislite da ćete tako narod pridobiti za svoju politiku. Možda hoćete Slovence, ne znam; možda ćete pridobiti začas i Srbe; ali stalno znam da Hrvate za to pridobiti nećete, a nećete ih pridobiti zato, jer je sav hrvatski seljački svijet isto tako protiv vašeg centralizma kako je protiv militarizma, isto tako za republiku kao i za narodni sporazum sa Srbima. I ako vi budete silom htjeli nametnuti svoj centralizam, evo što će se dogoditi. Mi ćemo Hrvati reći otvoreno, čisto i bistro: ,E, ako Srbi uistinu hoće da imadu takvu centralističku državu i vladu, Bog im je blagoslovio; ali mi Hrvati nećemo druge uredbe nego saveznu federativnu republiku'" ${ }^{27}$ Čak i kada je već bilo jasno da neće uspjeti u prolongiranju pregovora te će uslijediti spajanje sa Srbijom, Radić je predložio da novu državu privremeno vode tri regenta: srpski prestolonasljednik, hrvatski ban i predsjednik slovenskog Narodnog vijeća. Prema tom bi se planu konstituanta sastojala od 42 člana, od kojih bi po deset izabrala srpska skupština, Hrvatski sabor i slovensko Narodno vijeće (Narodni svet), bosanski bi sabor imao pravo birati četiri člana, dok bi Crna Gora u svojoj skupštini, jednako kao i dalmatinska skupština, predstavnici Vojvodine te Istra svaki odabrali još po dva člana. ${ }^{28}$ Međutim, Radić nije naišao na značajniju potporu, ovaj je njegov prijedlog poduprla samo grupa socijalista.

Krajem studenog 1918. činilo se kako je Radićeva ideja potpuno poražena te da će se ostvariti vizija HSK-a, odnosno bezuvjetno ujedinjenje sa Srbijom. Ono što je svakako bilo zanimljivo jest činjenica da su i mnogi hrvatski političari u toj političkoj grupaciji također tvrdili kako bi Država SHS i Kraljevina Srbija trebale preuzeti uloge koje bi bile adekvatne statusu poraženog, odnosno pobjednika u ratu, što je podrazumijevalo nejednakost dvaju entiteta unutar buduće države. Jedan od eksplicitnijih primjera obrane te teze jest onaj Mate Drinkovića: "Mi ne osnivamo ni Velike Srbije, ni Velike Hrvatske, ni Velike Slovenije, nego veliku, jaku i moćnu jugoslovensku državu. Moramo ipak glasno priznati, da je srpska kraljevina izašla u ovome ratu pobjednicom, a mi (Hrvati) da smo pobijeđeni. Razum i poštenje nalaže svakom patrioti, da u ovim velikim momentima istupi za narodno i državno jedinstvo." ${ }^{29} \mathrm{U}$ takvim je okolnostima odbor Narodnog vijeća SHS na kraju ipak imenovao 28 članova izaslanstva koje je dobilo

\footnotetext{
26 Ivašković, I., The Vidovdan Constitution and the Alternative Constitutional Strategies, Zbornik Pravnog fakulteta u Zagrebu, god. 68, br. 3-4, 2018., str. 525.-551.

27 Banac, I., Nacionalno pitanje u Jugoslaviji: porijeklo, povijest, politika, Globus, Zagreb, 1988., str. 216.

28 Prepeluh, op. cit. u bilj. 20, str. 171.-175. 
zadatak izvršenja odluke o spajanju. Toj je grupi dan i poseban dokument, takozvani "Naputak", u kojem je među ostalim bila i odredba kako konačnu vrstu organizacije države treba odrediti konstituanta s dvotrećinskom većinom. ${ }^{30}$ Međutim ti su uvjeti Narodnog vijeća SHS zanemareni, odnosno nitko od delegata nije se osvrtao na njih nakon dolaska u Beograd. U isto vrijeme srpska je diplomacija vješto spriječila povratak Antona Korošeca i Ante Trumbića iz Ženeve, čime je omogućila Svetozaru Pribićeviću preuzimanje uloge najvažnijega predstavnika Države SHS. Potonji je u tom razdoblju nastupao u funkciji provođenja hegemonističke politike Beograda, a pod njegovim je utjecajem Ante Pavelić (stomatolog) 1. prosinca 1918. pročitao izjavu kojom je vlast predao prestolonasljedniku Aleksandru Karađorđeviću. Srpski je regent proglasio spajanje Srbije i Države SHS, odnosno teritorija koje je zastupalo Narodno vijeće SHS. Prvoprosinački je akt, dakle, sastavljen od takozvane "adrese" delegacije Narodnog vijeća SHS, u kojoj se izražava želja po ujedinjenju, i "proklamacije” regenta Aleksandra Karađorđevića u kojoj pak isti prihvaća izraženu želju. ${ }^{31}$

Akt ujedinjenja nije izazvao samo nezadovoljstvo protivnika centralizma i srpske hegemonije, već je pokrenuo i čitav niz pravnih pitanja, odnosno nesuglasica između pobornika različitih južnoslavenskih koncepcija države. Dio hrvatske i slovenske elite ipak je pozdravio čin ujedinjenja. 3. prosinca je primjerice Narodno vijeće SHS u Zagrebu objavilo da je prestalo vršiti vrhovnu i suverenu vlast na području Države SHS te da "od 1. prosinca cijeli naš narod čini zajedničku slovensko-hrvatsko-srpsku državu pod regentstvom Njegovog kraljevskog visočanstva prestolonasljednika Aleksandra". ${ }^{32}$ I narodna vlada iz Ljubljane također je s oduševljenjem pozdravila spajanje u poruci kralju Petru i regentu Aleksandru: "Narodna vlada SHS u Ljubljani s iskrenim oduševljenjem pozdravlja ujedinjenje svih Srba, Hrvata i Slovenaca pod regentom Vašeg Kraljevskog Visočanstva ... Posebno se usuđujemo izraziti zahvalnost za blagohotna i utješna obećanja o odlučnijoj obrani cjelokupnog etnografskog teritorija SHS, posebno na našim sjevernim i zapadnim granicama ... Živio jugoslavenski Trst! Živjela jugoslavenska Gorica i Istra! Bog blagoslovi ujedinjenu Jugoslaviju! Bože sačuvaj kralja Petra i regenta Aleksandra!"33 Spominjanje Trsta, Gorice i Istre u kontekstu hvale kralju i njegovu nasljedniku izražavalo je slovenske nade da će ujedinjena velika jugoslavenska država na čelu s pobjedničkom srpskom kraljevskom dinastijom uspjeti spriječiti talijanske ambicije prema tim teritorijima. Ipak, među dijelom Slovenaca i još više u dijelu hrvatskog naroda pojavilo se negodovanje kako na samom terenu tako i pri tumačenju kako su se nekadašnji habsburški južnoslavenski teritoriji i narodi priključili Kraljevini Srbiji, koja je predstavljena kao osloboditeljica svih južnih Slavena s prirodnim pravom na širenje svog teritorija. ${ }^{34}$ Takvoj interpretaciji usprotivila se i grupa koja je dovela u pitanje zakonitost i legitimnost načina donošenja Prvoprosinačkog akta, tvrdeći kako je isti zapravo ništavan. Teza o nezakonitosti i nelegitimnosti čina ujedinjenja temeljila se na činjenici da potpisi nisu bili ratificirani u skupštinama ni na jednoj strani pred legitimnim predstavnicima dvaju međunarodnopravnih entiteta, nego je nova država

30 Sirotković, op. cit. u bilj. 16, str. 61.-74.

31 Treba napomenuti kako su sporazum praktički u cijelosti sastavili predstavnici Kraljevine Srbije te da je u prvoj privremenoj vladi od 20 ministara bilo 13 Srba, 4 Hrvata, 2 Slovenca i 1 bosansko-hercegovački musliman, čime je bilo omogućeno privremeno centralističko uređenje države (Engelsfeld, op. cit. u bilj. 23, str. 297.). Založba Obzorja, Maribor, 1977., str. 182.-183. 
rezultat djelovanja nelegitimnih predstavnika koji su iskoristili njima sklone međunarodne okolnosti. ${ }^{35}$ Doista, u procesu formiranja Kraljevine SHS zanemareni su brojni principi koji su dotad bili uobičajeni za pregovore prema međunarodnom pravu. Prije svega se to odnosilo na prekoračenje ovlasti Središnjeg odbora Narodnog vijeća SHS, koji nije tražio mišljenje vlastita plenuma. Ako i prihvatimo hipotetičku odsutnost državnih svojstava Države SHS, a samim tim i nepostojanje njezine državnosti, taj bi čin onda trebao odobriti Hrvatski sabor, odnosno Sabor Kraljevina Hrvatske, Slavonije i Dalmacije koji je držao vlast nad hrvatskim dijelom nekadašnjih habsburških južnoslavenskih teritorija, a čiji je subjektivitet nedvojbeno potvrđen pri raspadu Habsburške Monarhije. Na proces povezivanja s Kraljevinom Srbijom snažno je utjecalo tročlano predsjedništvo Središnjeg odbora Narodnog vijeća SHS, koje je za pregovore ovlastio izaslanstvo čiji članovi, međutim, nisu izabrani na plenarnoj sjednici, stoga pojedini pravnici $^{36}$ smatraju kako je akt udruživanja zapravo bio jednostrani čin regenta Aleksandra, koji je u svakom slučaju trebao ratifikaciju. Upravo zbog njezine odsutnosti neki su povjesničari okvalificirali spajanje kao nelegitiman čin koji je proveden u suprotnosti s tada važećim propisima. Umjerenija je tadašnja politička oporba pak tvrdila kako je Kraljevina SHS ipak nastala spajanjem dvaju jednakopravnih entiteta te da je nova država bila rezultat obostrane volje. Ovaj je stav, dakle, osporavao tezu o priključenju teritorija Države SHS Kraljevini Srbiji i zagovarao pravni diskontinuitet između stvorene države te bilo kojeg od dvaju entiteta koji su sudjelovali u njezinu formiranju.

Suparnika spajanja nije bilo malo ni u ostalim dotada značajnijim skupinama društva. To se neposredno manifestiralo već ustankom 5. prosinca u Zagrebu, ${ }^{37}$ no neuspjeh u nastojanju održanja granice na Drini, prijenos težišta vlasti na Beograd te prihvaćanje srpskog monarha predstavljalo je i potpuni poraz različitih pravaških pokreta te pravu katastrofu za katoličko svećenstvo Josipa Stadlera u BIH i za muslimansko stanovništvo uz rijeku Drinu. ${ }^{38}$ Način preuzimanja vlasti, koji je uključivao uvođenje smrtne kazne i postupanje na većinsko muslimanskim i hrvatskim područjima kao da su okupirani, a ne oslobođeni, prouzročilo je i spontane bune civilnog stanovništva. ${ }^{39}$ Ozbiljan udarac primila je također i slovenska katolička politička elita, u prvom redu dio Slovenske ljudske stranke koji je bio sklon Ivanu Šusteršiču. Naravno, Prvoprosinački je akt značio i poraz za one grupacije u Crnoj Gori i Srbiji koje su se nadale drugačijem političkom okviru nove države. Crnogorski je kralj Nikola nakon svrgnuća tražio podršku Italije, kamo se na kraju zajedno sa svojim sljedbenicima i povukao, dok su zagovornici neovisne Crne Gore podignuli ustanak koji je nova vlast krvavo ugušila. I socijaldemokratski su krugovi postajali sve radikalniji u protivljenju monarhijskom režimu. Potonji je naime prema svojoj prirodi bio protivan boljševičkom modelu koji je već bio uzeo maha u

35 Granda, S., Slovenija, Urad vlade za komuniciranje, Ljubljana, 2008., str. 198.

36 Vukas, B., ml., Hrvatska državnost - pravnopovijesne prosudbe, Pravni fakultet Sveučilišta u Rijeci, Rijeka, $2017 .$, str. 81.

37 Gabelica, M., Žrtve sukoba na Jelačićevom trgu 5. prosinca 1918., Časopis za suvremenu povijest, god. 37, br. 2, 2005., str. 467.477.

38 Zanimljivo je svjedočenje Ivana Meštrovića koji je u svojoj knjizi memoara opisao izjave nekadašnjeg urednika časopisa Slovenski jug Bože Markovića iz 1917. Prema njemu bi morali u poslijeratnom razdoblju na hrvatskim područjima bar na deset godina uvesti vojnu diktaturu, sve dok se Hrvati ne bi asimilirali i priučili državi. Još radikalniji je bio odnos do jugoslavenstva kod predstavnika vladajuće radikalne stranke. Meštrović tako prenosi izjavu Stojana Protića (1857. - 1923.): "Kad pređe naša vojska Drinu, dat ću Turcima dvadeset i četiri sata, pa makar i četrdesetosam, vremena da se vrate na pradjedovsku vjeru, a što ne bi htjelo, to posjeći, kao što smo u svoje vrijeme uradili u Srbiji” (Meštrović, I., Uspomene na političke ljude i događaje, Matica hrvatska, Zagreb, 1993., str. 73. 
Rusiji. Međutim, činjenica je kako su oporbene skupine pripadale različitim ideologijama, pa njihovo djelovanje protiv novog stanja nije bilo usklađeno. Posljedično su i pokušaji internacionalizacije jugoslavenskog problema ostali osuđeni na različite privatne inicijative. Tako je primjerice Stjepan Radić neuspješno pokušavao zainteresirati predstavnike velikih sila, pa se nakon neuspjeha u Londonu i Parizu odlučio svoju stranku ${ }^{40}$ učlaniti u seljačku interancionalu pod okriljem Kominterne. ${ }^{41}$

Može se stoga zaključiti da formiranje Kraljevine SHS nikako nije predstavljalo samo pobjedu jugoslavenske ideje, već je to bio trijumf specifičnog jugoslavenstva nauštrb više alternativnih državnih ideja, u prvom redu nasuprot neovisnoj hrvatskoj državi, potom i nasuprot republikanskoj ideji jugoslavenstva te također i u suprotnosti s federalnom idejom države južnih Slavena. Temeljni politički okvir ostvarene države doduše nije u potpunosti odgovarao nijednoj početnoj južnoslavenskoj viziji, ali je realizirani oblik ipak bio, s obzirom na geopolitičko i administrativno središte države te činjenicu kako je i formalnu vrhovnu vlast zauzimao srpski kralj, najbliži srpskoj ideji. Potonja je naime kao svoj glavni cilj slijedila ideju integracije svih područja naseljenih Srbima, koja će pak biti upravljana iz jednog centra pod kontrolom srpskog kralja. Brojnost poklonika različitih alternativnih ideja ipak opominje kako ne treba pojednostavnjivati južnoslavenski problem te baca drugačije svjetlo na pojedine teze kako je jugoslavenstvo, realizirano u Kraljevini SHS, bilo i prije ostvarenja prvoprosinačke države sastavnicom državnih projekata i željen državnopravni razvoj većine stanovništva s izuzetkom kosovskih Albanaca. ${ }^{42}$ Tako se primjerice izvan konteksta tumači stav austrougarskog generala Stjepana Sarkotića koji je u svojim pismima na jesen 1918. razočaran zaključio kako je i 60 \% Hrvata inficirano jugoslavenskom idejom. ${ }^{43}$ Južnoslavenski su koncepti naime bili toliko različiti da je praktički nemoguće govoriti o željama većine stanovništva, što je ukazivalo i na neusklađenost koncepata najvažnijih političkih stranaka. Istodobno je dihotomizacija južnoslavenske ideje na habsburšku i izvanhabsburšku varijantu također neprimjereno pojednostavnjenje, na što će ukazati rascjepkanost i posljedična neusklađenost opozicijskih struja na predstojećim izborima za konstituantu 1920. godine. ${ }^{44}$

\section{PITANJE PRAVNOG STATUSA DRŽAVE SHS}

Nakon formiranja Kraljevine SHS pojedinim je političkim skupinama oduzeta mogućnost legalnog djelovanja u stranačkom životu. Ostale oporbene stranke prihvatile su dani politički okvir, no svaka ih je značajnija anticentralistička aktivnost gurala prema rubu legalnosti. U okviru anticentralizacijske političke borbe korišten je niz pravnih instrumenata kojima se pokušavala dokazati opravdanost nužne promjene državnog uređenja. U tom je nastojanju za veću autonomiju pojedinih naroda unutar Kraljevine SHS bilo nužno oboriti pretežno srpske

Najprije je to bila Hrvatska pučka seljačka stranka, od 1920. Hrvatska republikanska seljačka stranka, a od 1925. Hrvatska seljačka stranka. 
teze, odnosno dokazati kako su teritoriji iz Habsburške Monarhije u Kraljevinu SHS ušli preko Države SHS, kojoj je barem formalnopravno bila jednakopravna u odnosu prema Kraljevini Srbiji. Time se pokušavalo opovrgnuti tezu prema kojoj je dominacija Srbije u Kraljevini SHS bila utemeljena na pravu, a drugi bi narodi trebali prihvatiti činjenicu kako su u ratu bili na strani poraženog i sukladno tome snositi posljedice. Prema istome je Srbija u ratu pretrpjela goleme gubitke upravo od poražene strane čije je teritorije potom anektirala, stoga je na potonje trebalo gledati kao svojevrsnu naplatu ratne štete. Utvrđivanje pravnog odnosa između Države SHS i Kraljevine Srbije te nastale Kraljevine SHS postalo je, dakle, prvoklasno političkopravno pitanje u razdoblju nakon Prvoprosinačkog akta jer je sa sobom nosilo brojne implikacije na ostale sfere društvenog života. Zagovornici unitarizma na jednoj i velikosrpske doktrine na drugoj strani branili su tezu o prijenosu pravnog subjektiviteta s Kraljevine Srbije na Kraljevinu SHS ispostavljajući upravo činjenicu srpske pobjede u ratu. U tom je kontekstu Habsburška Monarhija zbog ratnih sukoba prestala postojati, dok je Srbija nakon rata proširila svoju vlast na dio područja ratnog gubitnika.

Pri rješavanju dileme o pravnoj prirodi Države SHS, države čije je formiranje unatoč brojnim protestima ipak pozdravio i dio hrvatske javnosti, a još više slovenske javnosti, ${ }^{45}$ potrebno je najprije proučiti status ovog područja unutar Habsburške Monarhije, odnosno proces njegova izlaska iz realne unije Austrije i Ugarske. Hrvatska je unutar Monarhije nesumnjivo imala poseban pravni položaj utemeljen na konceptu hrvatskog državnog prava, a to je potvrđeno i Nagodbom iz 1868. ${ }^{46}$ Štoviše, Hrvatski je sabor donio odluku o ovlaštenju Narodnog vijeća SHS za pregovore s predstavnicima Kraljevine Srbije, pa su te delegirane ovlasti imale karakter iure mandata. ${ }^{47}$ Pritom je, dakako, od ključnoga značaja bila činjenica da je pri raspadu Habsburške Monarhije Hrvatski sabor usvojio pravne akte koji su ukazivali na suverenitet Hrvatske. ${ }^{48}$ Prvo je naime posebnim aktom raskinut državni savez s Austrijom i Ugarskom, a istodobno su se reinkorponirala područja koja su bila podijeljena u dva dijela Monarhije, što je ukazivalo na suverenitet Hrvatske. Hrvatska su područja dakle počela s pristupanjem novim državnim savezima tek nakon što su suverenom odlukom napustila Austro-Ugarsku. Hrvatski je sabor tek nakon toga odlučio prenijeti vlast na Narodno vijeće SHS, koje je na taj način postalo vrhovno političko tijelo na južnoslavenskim područjima sada već bivše Monarhije. Istovremeno, činjenica je kako dobar dio područja Države SHS nije bio pokriven hrvatskim državnim pravom, no volju za stupanje u Državu SHS ta su područja iskazala preko svojih predstavničkih tijela. Pojedini autori naglašavaju upravo tu činjenicu jer smatraju da u suvremenosti države više ne mogu nastajati izvorno, već moraju biti utemeljene iskazanom voljom subjekta koji je postojao na tim prostorima prije. Proces, dakle, mora biti u skladu s odredbama međunarodnog prava kako ne bi došlo do eskalacije nasilja. ${ }^{49} \mathrm{U}$ slučaju međunarodnopravnog subjektiviteta Države

45 Mal, J., Slovenci v desetletju 1918 - 1928, Leonova družba, Ljubljana, 1928., str. II.

46 Čepulo, D., Hrvatsko-ugarska nagodba i reforme institucija vlasti u Hrvatskom saboru 1868-1871, Zbornik Pravnog fakulteta u Rijeci, god. 22, br. 1, 2001., str. 117.-148.; Vukas, B., ml., op. cit. u bilj. 36, 2017., str. 76.

47 Čulinović, F., Državnopravna historija jugoslavenskih zemalja XIX. I XX. stoljeća - Hrvatska, Slavonija i Dalmacija, Istra, Srpska Vojvodina, Slovenija, Bosna i Hercegovina, Školska knjiga, Zagreb, 1956., str. 54.

48 "Hrvatski državni sabor na temelju potpunoga prava narodnoga samoodređenja, koje je danas već priznato od svih zaraćenih vlasti, stvara ovaj zaključak: Svi dosadašnji državno-pravni odnošaji i veze između kraljevine Hrvatske, Slavonije i Dalmacije s jedne strane, te kraljevine Ugarske i carevine Austrijske s druge strane, razrješavaju se." (Zaključak od 29. listopada 1918. u Boban, op. cit. u bilj. 15, str. 50.) 
SHS potrebno je analizirati u prvom redu sljedeće kriterije: definirani državni teritorij, stalno stanovništvo i učinkovitu vlast na cijelom području koja ima mogućnost neovisnog stupanja u odnose s drugim državama. ${ }^{50}$

U slučaju Države SHS, Narodno vijeće SHS doduše nije izričito definiralo državni teritorij na kojem je vršilo vlast, ali je teritorij bilo moguće jasno identificirati iz navoda prema kojem su to sva ona područja (Habsburške Monarhije) u kojima je stanovništvo pretežno južnoslavensko. ${ }^{51}$ Također, Narodno je vijeće u pravilniku o svom djelovanju definiralo: "Narodno vijeće za narod Slovenaca, Hrvata i Srba u Zagrebu političko je predstavništvo svih Slovenaca, Hrvata i Srba, koji žive u Hrvatskoj-Slavoniji, s Rijekom, u Dalmaciji, Bosni-Hercegovini, Istri, Trstu, Kranjskoj, Goričkoj, Štajerskoj, Koruškoj, Bački, Banatu, Baranji, Međimurju i po ostalim krajevima jugozapadne Ugarske." ${ }^{2}$ Naravno, može se postaviti pitanje je li ovaj teritorij dovoljno jasno definiran ili je možda već samo pristupanje Vojvodine Srbiji ukazivalo na činjenicu kako Država SHS ipak nije imala jasne državne granice. Međutim, subjektivitet države ne ovisi o jasno definiranom razgraničenju. ${ }^{53} \mathrm{Ni}$ danas naime mnoge zemlje, uključujući i mnoge države članice Ujedinjenih naroda, nemaju točno definirane granice, ali im to ne umanjuje njihov status države. Prema mišljenju većine pravnika ${ }^{54}$ ključni teritorijalni element državnosti odnosi se na njegovo jedro, odnosno središte teritorija neke zajednice koja se smatra državom, a to je u slučaju Države SHS bilo nesporno potvrđeno. Kriterij stalnog stanovništva ispunjen je posredno, tj. definicijom teritorija države, što je zapravo i inače najmanje problematičan kriterij. Najsporniji je zapravo bio posljednji kriterij državnosti, a to je efektivna vlast Narodnog vijeća SHS. Potonje naime nije kontroliralo određena područja nove državne formacije, ali je, unatoč određenim ograničenjima u vršenju stvarne vlasti, na kritičnom dijelu teritorija vršilo najvažnije državne dužnosti. Također je Narodno vijeće SHS bilo uključeno i u međunarodne odnose preko Jugoslavenskog odbora. ${ }^{55}$

U velikosrpskoj se doktrini najčešće naglašavao argument pomanjkanja međunarodnog priznanja Države SHS, što bi trebalo implicirati da se neki subjekt ne može smatrati državom sve dok ga druge države ne priznaju takvim. No pritom se prešućivala činjenica da država može biti priznata i posredno, odnosno preko stupanja u odnose s određenim entitetom kojemu se priznaje jednako pravo izražavanja vlastite volje u međudržavnim odnosima. To ukazuje na takozvano "tiho" ili neizravno priznanje. Vukas mlađi ${ }^{56}$ primjerice navodi da su u studenom 1918. godine državne vlasti, tj. Narodno vijeće SHS, primile nekoliko diplomatskih nota, među ostalim čak i obavijesti o imenovanju stranih diplomata u Državi SHS. Kao neizravni dokaz priznavanja subjektivnosti Države SHS možemo shvatiti i ravnopravno sudjelovanje njezinih predstavnika na Ženevskoj konferenciji od 6. do 9. studenoga 1918., što izravno uka-

50 Crawford J., The creation of states in international law, Clarendon, Oxford, 2007., str. 111.-119.

51 "Dalmacija, Hrvatska, Slavonija sa Rijekom proglašuje se posve nezavisnom državom prema Ugarskoj i Austriji, te prema modernom načelu narodnosti, a na temelju narodnoga jedinstva Slovenaca, Hrvata i Srba pristupa u zajedničku narodnu suverenu državu Slovenaca, Hrvata i Srba na cijelom etnografskom području toga naroda bez obzira na ma koje teritorijalne i državne granice, u kojima narod Slovenaca, Hrvata i Srba danas živi." (Zaključak od 29. listopada 1918. u Boban, op. cit. u bilj. 15, str. 51.)

52 Koprivica-Oštrić, op. cit. u bilj. 7, str. 52.

53 Andrassy, J.; Bakotić, B.; Vukas, B., op. cit. u bilj. 49, str. 69.

54 Petrič, E., Zunanja politika: osnove teorije in praksa, Center za evropsko prihodnost, Mengeš, 2010., str. 190.

55 Vukas, B., ml., Hrvatska državnost s gledišta međunarodnog prava, Pravni fakultet, Zagreb, 2002., str. 47.

56 Ibid., str. 45. 
zuje na sposobnost Države SHS za uspostavljanje ravnopravnih odnosa s drugim državama. Potonje je ujedno i najbolji dokaz da je ova država uspjela stupiti u odnose s drugim zemljama. Posljedično međunarodno priznanje samo pojačava međunarodni položaj subjekta, no nije i konstitutivni element državnosti. ${ }^{57}$ Takvo je stajalište potvrdila i Konvencija iz Montevidea o pravima i obvezama država koja je 1933. godine državu definirala kao "zajednicu određenog teritorija, stanovništva na tom teritoriju, suverene i učinkovite vlasti nad stanovništvom na tom području te sposobnosti uspostavljanja odnosa s drugim državama". ${ }^{58}$ To govori u prilog tezi o državnosti Države SHS, što su na kraju implicitno priznavali i neki tadašnji srpski ustavni pravnici. Slobodan Jovanović ${ }^{59}$ je primjerice još 1924. godine ustvrdio kako je odlukom Hrvatskoga sabora Hrvatska prenijela svoje ovlasti na Narodno vijeće SHS čime je prema njemu bila ukinuta neovisna hrvatska država u korist Države SHS.

\section{POLEMIKA IVANA ŽOLGERA O (DIS)KONTINUITETU KRALJEVINE SHS}

Rasprava o državnosti Države SHS predstavljala je samo jedan element u mnogo važnijoj dilemi koja je u to vrijeme ušla u politički život Kraljevine SHS. Pojavljivala su se naime različita stajališta u vezi s kontinuitetom, odnosno diskontinuitetom između tada postojeće države i Kraljevine Srbije. Naime, ako bi se održala teza o pravnom kontinuitetu, to bi podrazumijevalo da je Kraljevina SHS pravni nasljednik Kraljevine Srbije, dok bi teritoriji i narodi Države SHS predstavljali samo dodatak koji je Srbija stekla pobjedom u ratu bez obzira na status državnosti Države SHS. Interesantna je činjenica da je to pitanje prvo pokrenula Njemačka u okviru spora oko likvidacije njemačke imovine u Kraljevini SHS. Pritom je tvrdila da Kraljevina SHS, kao nova država, prema odredbama Versajskog ugovora nema ista prava kao druge savezničke države. Sporazum je naime podijelio poslijeratne zemlje na "nove" i "stare", što je impliciralo značajne ekonomske posljedice. Njemačka je tako bila obvezna nadoknaditi ratnu štetu samo civilnom stanovništvu državama Antante i stanovništvu teritorija koji su bili priključeni tim državama. ${ }^{60}$ Jedan od načina naplate štete predstavljalo je prenošenje njemačke imovine u tim zemljama na države ratnih pobjednika. ${ }^{61}$ Izuzeće je vrijedilo za nove zemlje koje nisu imale državnopravni subjektivitet u vrijeme rata ni kauze da bi mogle izvesti likvidaciju jer nisu ni postojale u vrijeme izvršenja štete. Unatoč tome i neke su od ovih zemalja također prisvojile njemačku imovinu, zbog čega je u 297. članku Versajskog ugovora omogućen povrat takve protupravno stečene imovine. Njemačka je to pravo mogla ostvariti pred ad hoc mješovitim sudovima, što je i pokušala u slučaju tužbe protiv Kraljevine SHS.

U konkretnom je slučaju, dakle, sud morao najprije odlučiti o prethodnom pitanju, tj. je li Kraljevina SHS nova ili stara država. Pritom je donekle iznenađujuće ustvrdio kako je Kralje-

\footnotetext{
57 Engelsfeld, op. cit. u bilj. 23, str. 290.

58 Montevideo Convention, 26. 12. 1933., članak 1.; Petrič, op. cit. u bilj. 54, str. 184.

59 Jovanović, S., Ustavno pravo Kraljevine Srba, Hrvata i Slovenaca, Službeni list SRJ, Beograd, 1995., str. 34.

60 Treaty of peace with Austria. St. Germain-en-Laye, 10. rujna 1919., članak 177. i 178.

61 The peace treaty of Versailles, 28. lipnja 1919., članak 243. i 297.
} 
vina SHS “stara” zemlja. Potonje je, razumljivo, išlo u prilog velikosrpskoj doktrini jer je s tim presuda navodno potvrdila kako je Kraljevina SHS ipak pravni nasljednik Kraljevine Srbije. Prema takvom tumačenju ime "Kraljevina SHS" predstavljalo je samo nov naziv za državu koja je u svojoj biti samo proširena predratna Kraljevina Srbija. Sudsku je presudu u slučaju Njemačke protiv Kraljevine SHS zadovoljno prokomentirao tada vodeći srpski pravnik, Dušan Subotić, koji je i sam bio član mješovitog sudskog vijeća u predmetnom sporu. Naglasio je da je sud pravni kontinuitet Kraljevine SHS razmatrao s međunarodnopravnog stajališta, te da se međunarodnopravni subjektivitet Kraljevine SHS temelji na državnopravnom subjektivitetu Kraljevine Srbije. ${ }^{62}$

Presuda unatoč nesklonoj političkoj klimi ipak ni u tadašnje vrijeme nije prošla nezapaženo, čak i kod pravnika koji su imali bitnu političku funkciju. Na presudu i popratni komentar Subotića uslijedio je naime odgovor Ivana Žolgera, inače uglednog pravnika i diplomata te člana mješovitih komisija koje su odlučivale o poslijeratnim državnim granicama Kraljevine SHS s Austrijom i Mađarskom. ${ }^{63}$ Žolger je u članku s naslovom "Da li je naša Kraljevina nova ili stara država?" analizirao mišljenje o kontinuitetu srpske države s gledišta međunarodnopravnih odredaba iz toga vremena, no pritom je analizirao i nadležnost konkretnoga suda pri donošenju konačne presude o pravnom karakteru država općenito. Najprije je ispostavio činjenicu da je "novost" zemlje formalne prirode, dok pravo na likvidaciju njemačke imovine proizlazi iz materijalnih činjenica, točnije iz činjenice "postojanja civilnog stanovništva koje je na ovaj ili onaj način (nezakonitim provođenjem neprijateljstava ili izvanrednih naredbi koje narušavaju imovinske odnose) oštećeno njemačkim postupkom" ${ }^{64}$ Nadalje je, prema mišljenju Žolgera, sud ocijenio novost države, iako je to bilo izvan njegove nadležnosti. Prema članku 297. Versajskog ugovora Kraljevina SHS nije nova država jer je doista imala civilno stanovništvo koje je u ratu bilo oštećeno njemačkim postupcima. Stoga je Žolger također smatrao, kao što je bilo i presuđeno, da njemačka tužba nije osnovana, ali je osporio pojednostavnjeno tumačenje suda oslonjeno na takozvani "valutni fakt". Sporazumi iz Saint-Germaina i Trianona su naime kod određivanja iznosa naknade zbog ratne štete definirali valutni odnos između zemlje koja plaća reparacije i zemlje koja ima pravo na odštetu, odnosno države primateljice. Kod isplate odštete trebao se primjenjivati ženevski tečaj koji je postojao dva mjeseca prije raspada Austro-Ugarske. U tom su se kontekstu Poljska i Čehoslovačka smatrale novim državama jer nisu imale vlastitu novčanu valutu za vrijeme rata. ${ }^{65}$ Analogno tome, činjenica kako je dinar postojao kao valuta u Kraljevini Srbiji, a zatim nakon rata i u Kraljevini SHS, bila je odlučujuća da sud potonju klasificira kao staru zemlju. Promatrajući slučaj s današnje točke gledišta kroz pravnu logiku tada važećih međunarodnih načela, možemo zaključiti da je Žolgerovo mišljenje bolje utemeljeno i pravno dosljednije. Postojanje međunarodno priznate valute za Kraljevinu SHS naime nije bio ni nužan, a još manje konstitutivan kriterij prema kojem bi se država mogla opredijeliti starom. Hipotetski se naime neka država može i odreći svoje monetarne suverenosti i prihvatiti valutu druge zemlje, ali to ne znači da se odrekla i svog međunarodnog subjektiviteta. Jedan takav atribut, koji je s vidika državnosti zapravo opskuran i prema kojem su se

\footnotetext{
62 Subotić, D., Naša Kraljevina nije nova država. Novi život. Knjiga XI., Grafički zavod Narodna Samouprava, Beograd, 1922.

63 Krizman, B., Vanjska politika jugoslavenske države 1918-1941. Diplomatsko-historijski pregled, Školska knjiga, Zagreb, 1975., str. 20.

64 Žolger, I., Da li je naša kraljevina nova ili stara država? Separat, Slovenski pravnik, br. 3-4, 1923., str. 7.

65 Treaty of peace with Austria, op. cit. u bilj. 60, članak 248.
} 
razlikovale Kraljevina SHS na jednoj i Poljska te Čehoslovačka na drugoj strani, nije mogao biti jedini i odlučujući faktor u razlikovanju stare i nove države. Mirovne sporazume, naime, treba tumačiti u skladu s njihovim poslanjem jer oni uglavnom samo određuju pojedinačna prava i obaveze država, dok njihov subjektivitet pretpostavljaju i ne spuštaju se u analizu njihova podrijetla. Dakle, čak je i u preambuli sporazuma iz Saint-Germaina navedeno samo to da se Austro-Ugarska kao država raspala, da su nastale "čehoslovačka” i "jugoslavenska” država te da su obje zemlje međunarodno priznate. Poslanje sporazuma bilo je, dakle, regulacija odnosa između država Antante i poraženih zemalja, ali sporazum ni na koji način nije posezao u akte već uspostavljenih država, niti je bio sklopljen s namjerom propitkivanja njihova načina konstituiranja.

Žolger u svojoj kritici presude, njezina obrazloženja i stava Dušana Subotića kao ključni kriterij određivanja "novosti” neke države ispostavlja njezino ustavno određenje. Prema njegovim riječima upravo temeljni ustavni akt određuje utemeljuje li neka država svoju opstojnost s oslanjanjem na prethodnu državu, odnosno postoji li pravni kontinuitet između Ustava sadašnje i prošle države, ili se pak sadašnji Ustav od prošle državne tvorbe i njezina ustavnog uređenja ograđuje, a pritom nije bitno je li ograđivanje eksplicitno ili implicitno. ${ }^{66}$ Prema istom autoru nije bilo nikakve sumnje da privremeni ustavni akt Kraljevine SHS nije bio stvoren prema normama Ustava Kraljevine Srbije iz 1903., što implicira prekid kontinuiteta između prošle srpske države i nove države Srba, Hrvata i Slovenaca. Postupak donošenja privremenog Ustava Kraljevine SHS naime nije bio u skladu s odredbama srbijanskog Ustava i njezina članka 200. kojim su bili definirani jedini mogući postupci prema kojima se u Kraljevini Srbiji moglo donositi ustavne promjene. Kao rezultat toga, dakle, uspostava Kraljevine SHS predstavljala je kršenje i posljedično prekid ustavnog poretka Kraljevine Srbije. Dodamo li k tomu i činjenicu neprovođenja "Naputka”, možemo se složiti s Ferdom Čulinovićem koji je smatrao da je Prvoprosinački akt "po svome porijeklu on je više oktroj, jer niti je za tu proklamaciju regent imao oslona u ,Naputku' Narodnog vieća u Zagrebu, niti ovlaštenja u odredbama srbijanskog Ustava od 1903. godine.” ${ }^{67}$ Štoviše, neustavnost Prvoprosinačkog akta s aspekta Ustava Kraljevine Srbije iz 1903. također je proizlazila iz činjenice da je Kraljevinu SHS proglasio regent, a ne kralj koji je jedini imao pravo na eventualno teritorijalno proširenje Srbije. ${ }^{68}$

Prekid kontinuiteta između Kraljevine Srbije i Kraljevine SHS imao je osnovu u međunarodnom sporazumu koji nije slijedio pravila srpskog Ustava jer međunarodni sporazum nije bio potvrđen u skupštini Kraljevine Srbije, kako je to bio predviđao članak 52. njezina Ustava. ${ }^{69}$ Vlada Kraljevine SHS također je bila sastavljena protivno odredbama ovog Ustava te je svoj legitimitet temeljila na istom, neratificiranom međunarodnom sporazumu. Ključni argument za pravni diskontinuitet između Kraljevine Srbije i Kraljevine SHS bio je, dakle, skriven u Prvoprosinačkom aktu koji je predstavljao međunarodni sporazum, a čija je bit bila određivanje postupka izrade novog Ustava, koji pak ni na koji način nije tražio uporište u srpskom Ustavu, niti je tada bio poznat u međunarodnom pravu. U ovom slučaju naime nije bilo cesije, debelacije, okupacije ili akcesije, što su bile jedine priznate mogućnosti povećanja, odnosno proširenja

66 Žolger, op. cit. u bilj. 64, str. 11.

67 Čulinović, op. cit. u bilj. 45, str. 210.-211.

68 Koprivica-Oštrić, op. cit. u bilj. 7, str. 69.

69 Ustav za Kraljevinu Srbiju, Državna štamparija Kraljevine Srbije, Beograd, 1903., članak 52. 
neke države prema tadašnjem međunarodnom pravu. ${ }^{70} \mathrm{U}$ slučaju formiranja Kraljevine SHS dogodilo se upravo suprotno. Kraljevina Srbija je naime sklopila sporazum s predstavnicima Države SHS, priznajući time njezinu ravnopravnost, što ukazuje na čin spajanja, a to je uz raspad, secesiju i dekolonizaciju predstavljalo jedan oblik derivativnog nastanka države. ${ }^{71}$

Na temelju navedenoga može se zaključiti kako je Narodno vijeće SHS (na području Države SHS) imalo iste ovlasti kao i najviši instituti vlasti u Kraljevini Srbiji. To je vidljivo i iz akta Narodnog vijeća SHS od 3. prosinca 1918. kojim je to tijelo odustalo od vršenja vlasti i istu prenio na srpskog regenta. Država SHS stoga nije ušla u Kraljevinu Srbiju, već je s njom uspostavila novu državu, što su na kraju krajeva implicitno potvrdili i neki od sljedbenika unitarističke ideje koji su govorili o ujedinjenju i spajanju. ${ }^{72}$ Spajanje podrazumijeva stvaranje novog entiteta i posljedično prestanak postojanja dvaju prethodnih, što nije osporeno ni činjenicom da je dinastija Karađorđević zadržala svoju funkciju i u novoj državi. Položaj kraljevske obitelji bio je određen predmetnim sporazumom, a isto je vrijedilo i sa zakonodavnom te izvršnom vlašću, državnim teritorijem i narodom. Uz to i na simboličkoj razini novi naziv i novi simboli označavaju državnopravnu odvojenost Kraljevine Srbije i Kraljevine SHS.

Analizirajući stav Subotića i Žolgera možemo zaključiti kako je prvi na odnos međunarodnog i unutarnjeg prava očigledno gledao kroz dualističku prizmu. Samo se time naime može objasniti tvrdnja da neka država može biti istovremeno stara prema međunarodnom i nova prema svom unutarnjem pravu. Sukladno tome Subotić je smatrao da je u slučaju Kraljevine SHS konstituiran nov ustavni poredak, dakle novo unutarnje uređenje, dok je ista država na međunarodnom planu naslijedila međunarodni položaj Kraljevine Srbije. Suprotno je tome stajalištu Žolger već samu dualističku teoriju smatrao besmislenom, jer je ista prema njemu onemogućavala relevantno prosuđivanje akata konstituiranja neke države. Čvrsto je zagovarao poziciju monističke paradigme prema kojoj se međunarodnopravna priroda nekog subjekta ne može prosuđivati odvojeno od unutarnje-pravne biti države. S tim u svezi, u međunarodnopravnim predmetima ne može se kao konstitutivna uzeti presuda o prethodnom pitanju iz nekog drugog postupka, čija osnovna svrha nije rješavanje istog pitanja. Stoga navedena valutna klauzula nije mogla biti relevantna za definiranje međunarodnopravnog položaja Kraljevine SHS jer valuta nije čimbenik koji bi mogao odrediti državnu bit. Nedosljednost prosuđivanja (dis)kontinuiteta države s oslanjanjem na pojedinačne međunarodnopravne akte koji se ne bave suštinom države Žolger je potkrijepio primjerom ugovora između Kraljevine SHS i takozvanim Glavnim silama iz 1919. godine. Taj je ugovor potvrdio da su Srbi, Hrvati i Slovenci iz bivše Austro-Ugarske Monarhije odlučili svojom voljom ujediniti se sa Srbijom kako bi stvorili jednu neovisnu i ujedinjenu državu po imenu Kraljevina Srba, Hrvata i Slovenaca. ${ }^{73}$ Posljedično Srbija nije proširila svoj suverenitet na nekadašnje austrougarske teritorije jer su

70 Žolger, op. cit. u bilj. 64, str. 13.

71 Türk, D., Temelji mednarodnega prava, GV Založba, Ljubljana, 2007., str. 89.

72 Primjerice Milan Pribićević, Svetozarov brat, u pismu Seatonu Watsonu pisao je kako je riječ o ujedinjenju južnoslavenskih zemalja: "Ujedinjenje južnoslovenskih država je svršen čin i sve razlike su izbrisane. Novu vladu u Beogradu čine predstavnici svih srpskih, slovenačkih i hrvatskih stranaka uključujući i jednog socijalistu. Svog predstavnika u kabinetu nema jedino stranka g. Radića. Tu stranku čini nekoliko seljaka koji su svi ekstremisti i nemaju konstruktivni program. To je samo mali ,boljševički` pokret bez imalo važnosti i s vrlo malim brojem simpatizera. Veoma sam zadovoljan što su svi nesporazumi i sitne zađevice između jugoslovenskog Narodnog vijeća i srpske vlade umrli prirodnom smrću onog trenutka kad je glavna ideja nacionalnog jedinstva ostvarena." (Đokić, op. cit. u bilj. 40, str. 65.) 
Slovenci, Hrvati i Srbi s tih prostora svojom voljom prenijeli svoj suverenitet na novostvorenu državu, što je impliciralo novi izvorni suverenitet. Indikativno je da su to potvrdili i neki slovenski unitaristi, točnije predstavnici liberalnog slovenskog političkog kruga koji se zalagao za uniju sa Srbijom. ${ }^{74}$ Tako je primjerice Ivan Tavčar već 6 . lipnja 1919. na saboru povjerenika Jugoslavenske demokratske stranke (JDS) izjavio kako žele biti postojani sluge novoj(!) državi. ${ }^{75}$

\section{ZAKLJUČAK}

Analiza dvaju ključnih državnopravnih pitanja koje se odnose na formiranje južnoslavenskih državnih tvorbi nakon Prvog svjetskog rata otežana je činjenicom da međunarodno pravo tada nije poznavalo sve pravne instrumente koji danas određuju položaj subjekata u međudržavnim odnosima. Unatoč tomu pravni argumenti ipak potvrđuju državnost Države SHS koja se konstituirala na području raspadnute Austro-Ugarske preko legitimnih predstavničkih tije$l^{76}$ te je de facto bila složena država. U tom kontekstu hrvatska je država promijenila vlast te se stavila pod novi suverenitet Narodnoga vijeća SHS, no nije ukinula nijednu svoju instituciju. Iako nije postojalo formalno međunarodno priznanje Države SHS, to prema deklarativnoj teoriji i nije konstitutivni element državnosti, stoga se može zaključiti kako je ova državna tvorba ipak ispunjavala sve osnovne kriterije međunarodnog subjektiviteta koji su kasnije i formalno određeni Konvencijom iz Montevidea, a to su trajno stanovništvo, teritorij, efektivna vlast i mogućnost stupanja u odnose s drugim državama. ${ }^{77}$ Također se možemo složiti i s tvrdnjom da je država imala pravnu sposobnost uspostavljanja odnosa s drugim subjektima međunarodnog prava. Štoviše, iz kratkog života Države SHS mogu se primijetiti i implicitni akti priznanja te države od strane drugih međunarodnih subjekta koji su postavljali institucije za stupanje u odnos i komunikaciju s predstavnicima Države SHS.

U razdoblju od formiranja Države SHS do njezina udruživanja s Kraljevinom Srbijom Stjepan Radić je u Hrvatskom saboru marginaliziran kao zastupnik koncepta povijesnog hrvatskog državnog prava. Za potonje se među tadašnjim, a i današnjim srpskim političkim i povjesničarskim krugovima moglo čuti kako je nedosljedan koncept jer bi stvaranje Hrvatske na tom temelju bilo u konfliktu s povijesnim pravima drugih naroda, primjerice Mađara. Međutim, takva objašnjenja nisu utemeljena jer koncept formiranja države na hrvatskoj državnopravnoj osnovi nije negirao postojanje mađarskog državnog prava i međunarodnog subjektiviteta mađarske države, tek je eventualno dovodio u pitanje njegovu teritorijalnu dimenziju. S druge je pak strane unitaristička jugoslavenska doktrina negirala kako postojanje hrvatskog državnog prava tako i mogućnost postojanja bilo kakvog drugog državnog subjekta na bilo kojem južnoslavenskom području (izuzevši bugarski), osim onoga koji bi se temeljio na državnopravnoj tradiciji Kraljevine Srbije.

74 Zečević, M., Na zgodovinski prelomnici, Založba Obzorja, Maribor, 1986., str. 89.

75 Perovšek, Liberalizem in vprašanje slovenstva, Modrijan, Ljubljana, 1996., str. 142.

76 Ta je legitimnost ipak bila ograničena jer primjerice na području Hrvatske i Slavonije do 1918. nije bilo općeg prava glasa te je sastav Hrvatskoga sabora određivalo samo 8 posto stanovništva, što je i legitimnost relativne većine Hrvatsko-srpske koalicije stavljalo pod upitnik (Krizman, B., op. cit. u bilj. 24, str. 27.) 
Analiza Prvoprosinačkog akta dovodi do zaključka da je postupak spajanja uključivao kršenje ovlasti Narodnog vijeća SHS, odnosno da potonje nije u cijelosti konzumiralo svoje pravo u skladu intencijom Hrvatskoga sabora i njegova zaključka od 29. listopada ${ }^{78}$ jer nije uključivao naknadnu ratifikaciju vlastita plenuma, nego je većinu odluka donio tročlani Središnji odbor. Čak i pri samom činu spajanja Narodno je vijeće SHS ovlastilo 28 članova koji, međutim, nisu bili izabrani na plenarnom zasjedanju. Osim toga, izaslanstvo koje je otišlo u Beograd, ignoriralo je „Naputak“ i sam potpisani akt nije dobio potrebnu ratifikaciju Skupštine na drugoj strani, što bi bilo u skladu s tada važećim uređenjem Kraljevine Srbije. Stoga je ujedinjenje bilo izvedeno preko ovlasti što se tiče hrvatske strane i mimo Ustava, ako ga promatramo sa srpske strane. Upravo je ovaj pravni moment zasigurno jedan od ključnih faktora koji nas vode do zaključka kako je Kraljevina SHS ipak bila nova država jer je ista dobila novi Ustav koji je prekinuo kontinuitet prethodnog srpskog Ustava, a samim time i kontinuitet Kraljevine Srbije. Privremeno uređenje koje je Kraljevina SHS dobila 1. prosinca 1918. naime nije bilo stvoreno prema normama odredaba srpskog ustava iz 1903. godine, već je bilo rezultat sporazumnog prijeloma ustavnog poretka Kraljevine Srbije postignutog međunarodnim sporazumom između dva formalno jednakopravna subjekta. Vlada nove države temeljila je svoj legitimitet upravo na tom međunarodnom sporazumu.

Unatoč formalnoj jednakosti stvarne pregovaračke pozicije nisu omogućavale istinski jednakopravne uvjete jednoj i drugoj strani. Očita je naime bila nadmoć predstavnika Kraljevine Srbije, što se odrazilo u procesu oblikovanja novog ustavnog uređenja i na kraju potvrdilo Vidovdanskim ustavom. Potonji je uključivao sve ključne zahtjeve pretežito srpskih vlasti te je potvrdio premoć velikosrpske nacionalne ideologije. No, to ipak nije dovoljno da bi se priklonili tezi nekih pravnika ${ }^{79}$ kako je u slučaju formiranja nove države došlo do priključenja Države SHS ka Kraljevini Srbiji. Na kraju možemo zaključiti kako s pravnog aspekta velikih nedoumica u ovom predmetu nije ni bilo, no presuda u slučaju međunarodnopravnog spora Njemačke i Kraljevine SHS i još više njezina različita tumačenja ukazali su kako na velike razmjere unutarnjih političkih prijepora u novoj državi, tako i na čestu političku pragmatičnost međunarodnih čimbenika. Utjecaj potonjih na unutarnje prilike u Kraljevini SHS/Jugoslaviji upravo zbog nedostatka unutarnje kohezije, što se jasno pokazalo i u pitanju koje obrađuje predmetni članak, povećavat će se zapravo sve do prestanka njezina postojanja.

\section{LITERATURA}

1. Andrassy, J.; Bakotić, B.; Vukas, B., Međunarodno pravo, Školska knjiga, Zagreb, 1995.

2. Banac, I., Nacionalno pitanje u Jugoslaviji: porijeklo, povijest, politika, Globus, Zagreb, 1988.

3. Banac, I., Emperor Karl Has Become a Comitadji: The Croatian Disturbances of Autumn 1918, The Slavonic and East European Review, god.70, br. 2, 1992., str. 284.-305.

4. Boban, L., Kada je i kako nastala Država Slovenaca, Hrvata i Srba, Časopis za suvremenu povijest, god. 24, br. 3, 1992., str. 45.-60.

78 Boban (op. cit. u bilj. 15, str. 59.) smatra da stoga za Hrvatski sabor Prvoprosinački akt nije bio obvezan.

79 Primjerice Ribičič, C., Ustavnopravni vidiki osamosvajanja Slovenije, Časopisni zavod Uradni list Republike Slovenije, Ljubljana, 1992., str. 6. 
5. Crawford, J., The creation of states in international law, Clarendon, Oxford, 2007.

6. Čepulo, D., Hrvatsko-ugarska nagodba i reforme institucija vlasti u Hrvatskom saboru 1868-1871, Zbornik Pravnog fakulteta u Rijeci, god. 22, br. 1, 2001., str. 117-148.

7. Čepulo, D.; Margetić, L.; Beuc I., Hrvatska pravna povijest u europskom kontekstu, Pravni fakultet, Zagreb, 2006.

8. Čulinović, F., Državnopravna historija jugoslavenskih zemalja XIX. I XX. stoljeća-Hrvatska, Slavonija i Dalmacija, Istra, Srpska Vojvodina, Slovenija, Bosna i Hercegovina, Školska knjiga, Zagreb, 1956.

9. Čulinović, F., Tri etape nacionalnog pitanja u jugoslovenskim zemljama, Jugoslavenska akademija znanosti i umjetnosti, Zagreb, 1962.

10. Čulinović, F., Državnopravni razvitak Jugoslavije, Školska knjiga, Zagreb, 1963.

11. Đokić, D., Nedostižni kompromis. Srpsko-hrvatsko pitanje u međuratnoj Jugoslaviji, Fabrika knjiga, Beograd, 2010.

12. Engelsfeld, N., Povijest hrvatske države i prava - razdoblje od 18. do 20. stoljeća, Pravni fakultet, Zagreb, 2002.

13. Gabelica, M., Žrtve sukoba na Jelačićevom trgu 5. prosinca 1918., Časopis za suvremenu povijest, god. 37, br. 2, 2005., str. 467.-477.

14. Granda, S., Slovenija, Urad vlade za komuniciranje, Ljubljana, 2008.

15. Ivašković, I., The Implications of the „New Course"Strategy, Croatian Political Science Review, god. 56, br. 3-4, 2019., str. 218.-238.

16. Ivašković, I., The Vidovdan Constitution and the Alternative Constitutional Strategies, Zbornik Pravnog fakulteta u Zagrebu, god. 68, br. 3-4, 2018., str. 525.-551.

17. Jovanović, S., Ustavno pravo Kraljevine Srba, Hrvata i Slovenaca, Službeni list SRJ, Beograd, 1995.

18. Koprivica-Oštrić, S., Konstituiranje Države Slovenaca, Hrvata i Srba 29. listopada 1918. godine, Časopis za suvremenu povijest, god. 25, br. 1, 1992., str. 45.-71.

19. Krizman, B., Vanjska politika jugoslavenske države 1918-1941. Diplomatsko-historijski pregled, Školska knjiga, Zagreb, 1975.

20. Krizman, B., Hrvatska u prvom svjetskom ratu: hrvatsko-srpski politički odnosi, Globus, Zagreb, 1989.

21. Kovač, M., Raspadanje Austro-Ugarske i rađanje Kraljevine SHS u svjetlu francuske politike (od listopada do prosinca 1918.), Časopis za suvremenu povijest, god. 35, br. 1, 2003., str. 141.-172.

22. Lampe, J. R., Yugoslavia as history. Twice there was a country. Second edition, Cambridge University press, Cambridge, 2002.

23. Lavrič, J., Mal, J., Stele, F. (ur.), Spominski zbornik Slovenije, Jubilej, Ljubljana, 1939.

24. Lukan, W., Iz „črnožolte kletke narodov“ v „zlato svobodo“? Habsburška monarhija in Slovenci v prvi svetovni vojni, Znanstvena založba Filozofske fakultete Univerze v Ljubljani, Ljubljana, 2014.

25. Mal, J. (ur.), Slovenci v desetletju 1918 - 1928, Leonova družba, Ljubljana, 1928.

26. Meštrović, I., Uspomene na političke ljude i događaje, Matica hrvatska, Zagreb, 1993.

27. Montevideo Convention, 26. 12. 1933, http://www.cfr.org/sovereignty/montevideo-convention-rights-duties-states/p15897. Pristupljeno 27. prosinca 2017.

28. Perovšek, J., Liberalizem in vprašanje slovenstva, Modrijan, Ljubljana, 1996.

29. Perovšek, J., Slovenska osamosvojitev v letu 1918, Modrijan, Ljubljana, 1998.

30. Perovšek, J., Jugoslovanska združitev. U: Borak, N.; Fisher, J., (ur.), Slovenska novejša zgodovina 1848-1992, Mladinska knjiga, Inštitut za novejšo zgodovino, Ljubljana, 2005.

31. Petrič, E., Zunanja politika: osnove teorije in praksa, Center za evropsko prihodnost, Mengeš, 2010. 
32. Pilar, I., Južnoslavensko pitanje: prikaz cjelokupnog pitanja/L.V. Südland, Hrvatska demokratska stranka, Varaždin, 1990.

33. Pleterski, J., Prva odločitev Slovencev za Jugoslavijo, Slovenska matica, Ljubljana, 1971.

34. Popov, Č.; Mitrović, A., Istorija srpskog naroda. Knjiga šesta. Od Berlinskog kongresa do ujedinjenja 1878-1918, Srpska književna zaklada, Beogard, 1983.

35. Prepeluh, A., Pripombe k naši prevratni dobi, Založništvo tržaškega tiska, Trst, 1987.

36. Prunk, J.; Toplak, C.; Hočevar, M., Parlamentarna izkušnja Slovencev, Fakulteta za družbene vede, Ljubljana, 2006.

37. Radić, S., Politički spisi: Autobiografija, članci, govori, rasprave, Znanje, Zagreb, 1971.

38. Rahten, A., Slovenska ljudska stranka v beograjski skupščini. Jugoslovanski klub v parlamentarnem življenju Kraljevine SHS 1919-1929, Založba ZRC, Ljubljana, 2002.

39. Ribičič, C., Ustavnopravni vidiki osamosvajanja Slovenije, Časopisni zavod Uradni list Republike Slovenije, Ljubljana, 1992.

40. Sirotković, H., O nastanku, organizaciji, državnopravnim pitanjima i sukcesiji Države SHS nastale u jesen 1918., Časopis za suvremenu povijest, god. 24, br. 3, 1992., str. 61.-74.

41. Sirotković, H.; Margetić, L., Povijest država i prava naroda SFR Jugoslavije, Školska knjiga, Zagreb, 1988.

42. Stavbar, V., Majniška deklaracija in deklaracijsko gibanje, Založba Pivec, Maribor, 2017.

43. Subotić, D., Naša Kraljevina nije nova država. Novi život. Knjiga XI., Grafički zavod Narodna Samouprava, Beograd, 1922.

44. Šišić, F., Dokumenti o postanku Kraljevine Srba, Hrvata i Slovenaca, 1914-1919, Matica hrvatska, Zagreb, 1920.

45. The peace treaty of Versailles, 28. 6. 1919., http://net.lib.byu.edu/ rdh7/wwi/ versailles. html. Pristupljeno 21. svibnja 2017.

46. Treaty of peace with Austria. St. Germain-en-Laye, 10. 9. 1919., http://www.austlii.edu. au/au/other/ dfat/treaties/1920/3.html. Pristupljeno 30. svibnja 2017.

47. Türk, D., Temelji mednarodnega prava, GV Založba, Ljubljana, 2007.

48. Ustav za Kraljevinu Srbiju, Državna štamparija Kraljevine Srbije, Beograd, $1903 .$.

49. Vukas, B., ml., Hrvatska državnost s gledišta međunarodnog prava, Pravni fakultet, Zagreb, 2002.

50. Vukas, B., ml., Hrvatska državnost - pravnopovijesne prosudbe, Pravni fakultet Sveučilišta u Rijeci, Rijeka, 2017.

51. Zečević, M., Slovenska ljudska stranka in jugoslovansko zedinjenje 1917-1921: Od majniške deklaracije do vidovdanske ustave, Založba Obzorja, Maribor, 1977.

52. Zečević, M., Na zgodovinski prelomnici: Slovenci v politiki jugoslovanske države 1918-1929, Založba Obzorja, Maribor, 1986.

53. Žolger, I., Da li je naša kraljevina nova ili stara država? Separat. Slovenski pravnik, 1923., br. 3-4, str. 1.-18. 
Igor Ivašković*

\section{CONTROVERSIES OVER THE STATUS OF THE STATE AND KINGDOM OF SCS}

\section{Summary}

The article aims mainly at analyzing the issue of legal (dis)continuity between the Kingdom of Serbia and the Kingdom of Serbs, Croats and Slovenes (hereinafter the Kingdom of SCS) within the context of an international dispute between Germany and the Kingdom of SCS, and to revealing the reasons for different court decisions interpretations in a particular case. By using the techniques of historical-legal and analytical methods in researching into documents and secondary opinions given by politicians and constitutional lawyers, the paper first gives a brief overview of international circumstances that enabled the post-war states formation. It also summarizes different opinions regarding the legal status of the State of SCS and the character of the First-December Act taking into account historical and modern international and constitutional criteria. The conclusion is made in the context of discussion regarding the central issue that Ivan Žolger's interpretation that despite the verdict in the particular case, the Kingdom of SCS was a new state, since it was not created in accordance with the 1903 Constitution of the Kingdom of Serbia. In addition to the argument that the State of SCS met the basic criteria of statehood, and that the formation of the Kingdom of SCS interrupted the constitutional continuity of the Kingdom of Serbia, the contribution of the paper lies in the argument that different legal opinions were not so much the result of legal ambiguities, but primarily a reflection of one, out of many, political battles fought between the conflicting state ideologies.

Keywords: $\quad$ Constitutional law, Kingdom of SCS, Kingdom of Serbia, State of SCS, Yugoslav ideologies

\section{(c) (1) (9)}

This work is licensed under a Creative Commons

Attribution-NonCommercial 4.0 International License.

Igor Ivašković, PhD, Assistant Professor, School of economics and business, University of Ljubljana, Kardeljeva ploščad 17, 1000 